\title{
KAJIAN TEOLOGIS TENTANG PENYEMBAHAN BERDASARKAN INJIL YOHANES 4:24
}

\author{
Hengki Wijaya ${ }^{1) *}$ \\ 1) Lembaga Penelitian dan Penerbitan Sekolah Tinggi Theologia Jaffray \\ ${ }^{*}$ Penulis korespondensi: hengkiwijaya@sttjaffray.ac.id
}

\begin{abstract}
Abstrak
Tujuan penulisan artikel ini adalah mengetahui arti penyembahan berdasarkan Injil Yohanes 4:24, implikasi teologis tentang penyembahan, dan sikap dan cara menyembah Bapa dalam roh dan kebenaran. Penyembahan yang sejati menurut Alkitab adalah menyembah Allah yang benar di dalam roh yang diperbarui oleh Roh Kudus dan hidup sesuai dengan kebenaran Allah yaitu mengenal pribadi Yesus sebagai air hidup. Implikasi teologis biblika adalah Allah adalah Roh maka Allah harus disembah di dalam roh (batiniah yang diperbarui oleh Roh Kudus), dan bukan disembah secara lahiriah saja atau yang tampak secara jasmani. Allah saja yang harus disembah oleh manusia, tidak ada yang lain. Secara praktis orang percaya harus menyembah Allah dengan sikap yang benar dibarui oleh Roh Kudus dan hidup sesuai dengan kebenaran-Nya. Sikap penyembahan yang benar adalah sikap hati yang memuliakan Tuhan karena pengorbanan-Nya yang menyelamatkan di mana setiap orang percaya menyembah satu-satunya Juruselamat dan memberitakan-Nya dalam kehidupan orang percaya.
\end{abstract}

Kata-kata kunci: menyembah, roh, kebenaran, Injil Yohanes, sikap, Roh Kudus, orang Samaria

The purpose of this article is to understand the meaning of worship based on John 4:24, the theological implication concerning worship and the attitudes and the manner of worshipping the Father in spirit and in truth. True worship from a biblical viewpoint is worshipping the true God with a spirit that is renewed by the Holy Spirit and living in accordance with the truth of God, that is, to know Jesus personally as the Living Water. The implication for biblical theology is that God is Spirit, so God is worshiped in spirit (the inner being that is renewed by the Holy Spirit), and not only worshiped outwardly, in a physical manner. It is God alone that should be worshiped by human beings, there is no other. In practice believers should worship God with a right attitude that is renewed by the Holy Spirit and live in concordance with His righteousness. The attitude of true worship is an attitude of the heart that glorifies the Lord because of His sacrifice that saves, where believers worship the one and only Savior and tell the world about Him.

Keywords: worship, spirit, righteousness, John Gospel, attitude, Holy Spirit, Samaritan 


\section{Pendahuluan}

Isu "penyembahan" menjadi begitu penting terutama sekali bila dikaitkan dengan nas Injil Yohanes 4:24 “... Allah itu Roh dan barangsiapa menyembah Dia, harus menyembah-Nya dalam roh dan kebenaran." Kata "penyembahan" menjadi satu hal yang penting karena dihubungkan secara langsung dengan Allah sendiri. Djohan Handoyo salah satu pelopor pujian dan penyembahan di Indonesia menjelaskan: "Pribadi Allah adalah Roh. Dimensi penyembahan sebagai komunikasi antara kita dengan Tuhan membutuhkan bahasa roh sebagai penghubungnya."

Bagi kalangan "mainstream dan Injili“ arti penyembahan bukan hanya dalam liturgi gereja, tetapi pada seluruh aspek. Penyembahan yang benar adalah hidup yang benar sesuai firman Tuhan. Kalau pun penyembahan diartikan dalam liturgi ibadah maka penyembahan itu juga bukan praktik penyembahan di kalangan pietis. Makna seperti ini diantaranya disampaikan oleh John MacArthur :

"Penyembahan bukanlah masalah berada di tempat yang benar, pada waktu yang tepat. Penyembahan bukanlah kegiatan lahiriah yang menuntut terciptanya suasana tertentu. Penyembahan terjadi di dalam hati, dalam roh." "Sifat dasar penyembahan adalah memberikan penyembahan kepada Allah dari bagian diri kita yang paling dalam, dalam pujian, doa, nyanyian, memberi bantuan, dan hidup, selalu berdasarkan kebenaran-Nya yang dinyatakan."

Kata "penyembahan" sudah menjadi tren di dalam komunitas gereja, seperti istilah pujian dan penyembahan. Pernyataan bahwa orang percaya harus menyembah Bapa dalam Roh dan kebenaran adalah penyataan Alkitab, namun bagaimana cara melakukan penyembahan seperti itu, sekilas beberapa pandangan singkat telah dinyatakan di atas.

Berdasarkan isu-isu seputar penyembahan, penulis akan menguraikan kebenaran tentang kata "penyembahan" dan definisi penyembahan itu sendiri dengan pendekatan latar belakang konteks Yohanes 4 yang dihubungkan dengan penyembahan, arti kata penyembahan berdasarkan Alkitab yaitu berdasarkan kata "penyembahan" dalam Perjanjian Lama dan Perjanjian Baru khususnya Yohanes 4. Selanjutnya penulis memberikan pandangan-pandangan tentang definisi penyembahan, dan menjelaskan landasan teologi

\footnotetext{
${ }^{1}$ Djohan E. Handoyo, Praise and Worship (Yogyakarta: Penerbit ANDI, 2007), 50.

2 John MacArthur, Prioritas Utama dalam Penyembahan (Bandung: Kalam Hidup, 2001), 151 .

${ }^{3}$ MacArthur, Prioritas Utama dalam Penyembahan, 162.
} 
penyembahan berdasarkan Yohanes 4:24. Pada bagian akhir dibahas bagaimana menjadi penyembah dalam roh dan kebenaran.

\section{Eksposisi Penyembahan Berdasarkan Yohanes 4:24}

\section{Latar Belakang Konteks Yohanes 4:1-42}

Percakapan Tuhan Yesus dengan perempuan Samaria (Yoh. 4:1-42) merupakan dialog antara orang Yahudi dengan orang Samaria. Suatu perjumpaan yang tidak lazim bagi orang Yahudi. Orang Yahudi tidak bergaul dengan orang Samaria. Sebab mereka merupakan "bangsa campuran yang memiliki agama campuran, yang sekalipun demikian menerima Pentateukh dan mengaku menyembah Allah Israel."4

"Dalam naskah Kitab Ulangan yang diterima oleh bangsa Samaria pasal 27:4-5, Yosua diperintahkan mendirikan mezbah di Gunung Gerizim. Nas yang sama, dalam naskah yang diterima oleh umat Yahudi, berkata bahwa mezbah itu harus didirikan di Gunung Ebal, bukan gunung Gerizim. Bangsa Samaria menolak kitab-kitab suci yang lain, selain kelima Kitab Musa, maka mereka tidak menerima 2 Tawarikh 6:6, yang berkata,"Tetapi kemudian Aku memilih Yerusalem sebagai tempat kediaman nama-Ku dan memilih Daud untuk berkuasa atas umat-Ku Israel." ${ }^{5}$

Siapa perempuan itu tidak disebutkan secara jelas identitasnya. Ketika Yesus berada di sumur Yakub, Dia meminta air kepada perempuan tersebut. Namun demikian lebih dari sekadar kebutuhan akan air, Yesus "menunjukkan bahwa perempuan itu mempunyai kebutuhan yang lebih mendalam, yaitu kebutuhan yang dapat dipenuhi oleh Yesus melalui karunia Allah."6 Secara moral perempuan Samaria adalah orang berdosa dengan kehidupan pribadinya yang tidak benar, dan melalui masalah itu pula Yesus menyatakan kebenaran tentang keberadaan dan kebutuhannya dalam batin perempuan berdosa itu. Dalam percakapannya, perempuan itu berbicara tentang penyembahan dan membicarakan di mana sebenarnya tempat penyembahan. Namun Yesus menjelaskan kepadanya bahwa akan tiba bahwa penyembah itu harus menyembah Bapa (Allah) dalam roh dan kebenaran.

${ }^{4}$ Everett F. Horrison, "Yohanes" dalam Tafsiran Alkitab Wycliffe Vol.3 PB (Malang: Penerbit Gandum Mas, 2001), 315.

${ }^{5}$ Dave Hagelberg, Tafsiran Injil Yohanes Pasal 1-5 (Yogyakarta: Penerbit ANDI, 1999), 168

${ }^{6}$ Everett F. Horrison, "Yohanes" dalam Tafsiran Alkitab Wycliffe Vol. 3 PB (Malang: Penerbit Gandum Mas, 2001), 315. 


\section{Arti Kata Penyembahan dalam Alkitab}

Ada tiga kata utama dalam bahasa Ibrani yang digunakan dalam Perjanjian Lama untuk menjelaskan tentang penyembahan; yaitu kata yang sering diterjemahkan dalam versinya Inggris sebagai worship (penyembahan). Terminologi Alkitab menyatakan bahwa penyembahan adalah penundukkan diri, pelayanan, penghormatan.?

Kata yang paling umum untuk penyembahan dalam Perjanjian Lama adalah kata Ibrani hawah. Bentuk aslinya adalah hishtahawah, yang artinya bow down (bersujud), to do obeisance (menaruh hormat), to pay homage (memberi penghormatan), worship (menyembah). Ada 170 kali kemunculan kata hawah dalam Perjanjian Lama, hanya kurang dari setengahnya (kurang lebih 75 kali) yang diterjemahkan sebagai worship (menyembah) dalam versi NIV. Kurang lebih dalam jumlah yang sama, digunakan kata bow down. "Bersujud" jelas-jelas merupakan komponen yang penting dalam makna kata tersebut. Gerakan tubuh ini adalah suatu hal yang umum dalam kebudayaan dari waktu ke waktu. Membungkuk (bow) merupakan sebuah cara untuk menghormati seseorang; suatu tanda penghormatan. Membungkuk juga dapat bermakna menundukkan diri, khususnya ketika dilakukan di hadapan sosok seseorang yang berwenang. Tetapi satu hal yang penting dalam semuanya ini adalah tujuan di balik sikap tubuh yang ditunjukkan. Tentu saja, seperti sikap tubuh yang lain, tindakan ini dapat dilakukan hanya sebagai gerak fisik saja, sehingga bisa dimanipulasi. Namun, tindakan dan sikap hati harus berjalan bersama-sama. Jadi, sebagai istilah penyembah, hawah menyampaikan gagasan tentang menghormati Allah dan mengekspresikan sikap penundukan diri pada-Nya. ${ }^{8}$

Kelompok kata berikutnya menunjukkan bahwa penyembahan melibatkan kerja atau pelayanan. Istilah Ibrani yang relevan adalah 'abad'. Secara keseluruhan, kata ini ditemukan 289 kali dalam Perjanjian Lama. Artinya meliputi 'to work (bekerja)', 'to do (berbuat)', 'to perform (melakukan)', 'to serve (melayani)', 'to worship (menyembah)'. Dalam NIV, paling banyak diterjemahkan sebagai serve (melayani), kurang lebih 125 kali. Sering kali ini berada dalam konteks di mana Allah merupakan objek dari kata kerja; Seseorang yang dilayani. Frase to serve the Lord (melayani Tuhan/beribadah kepada Tuhan)' (Yahweh) digunakan sebanyak 56 kali. Penggunaannya mengandung kesan 'menyembah' (lihat Kel. 3:12; Ul. 10:12; Yes. 19:21), bahkan juga tempat di mana penerjemah

\footnotetext{
${ }^{7}$ Chris Jack, "Memahami Penyembahan: Bagian 2" dalam Menyembah dalam Roh dan Kebenaran, cetakan keenam (Yogyakarta: Penerbit ANDI, 2010), 80.

${ }^{8}$ Jack, "Memahami Penyembahan: Bagian 2" dalam Menyembah dalam Roh dan Kebenaran, cetakan keenam, 80-81.
} 
Alkitab memilih untuk menggunakan kata 'serve' daripada 'worship.' Seperti digunakan dalam berbagai konteks yang mengesankan pelayanan kepada Tuhan, kata abad juga secara khusus dipakai untuk kebaktian agamawi, termasuk yang berhubungan dengan pemujaan (tata cara pengorbanan dan lain-lain), contohnya dalam Bilangan 3:7; 8:11. Seluruh tata cara pengorbanan diberikan Allah untuk memampukan umat-Nya Israel untuk melayani (menyembah) Dia dengan cara yang benar. ${ }^{9}$

Kata Yunani proskuneo diringkas dengan baik oleh H. Schonweiss dan C. Brown dalam New International Dictionary of New Testament Theology 2:

Bagi orang-orang Yunani, kata kerja ini merupakan istilah teknis untuk pemujaan terhadap dewa, yang berarti tersungkur, menaklukkan diri, memuja dengan berlutut... selain sikap luar menaklukkan diri dalam penyembahan, proskuneo dapat menunjukkan sikap batin yang sesuai dengan penghormatan dan merendahkan diri. ${ }^{10}$

Kata proskuneo berarti "mencium ke arah," "mencium tangan," atau "membungkuk". Kata ini digambarkan seperti seekor anjing yang mengecup tangan tuannya. Kata penyembahan yang digunakan untuk menjelaskan pemujaan yang rendah hati. ${ }^{11}$ Bahasa Yunani menyembah proskuneo artinya memuja, suatu sikap seperti anjing menjilat tuannya." ${ }^{12}$ Suatu hubungan yang dekat, hormat, lembut, taat dan penuh kasih sayang yang harmonis. Pengertian Allah itu Roh, bukanlah hal asing dalam pengertian Yudaisme, tetapi Yesus menekankan bahwa penyembah-Nya pun harus selaras dengan Yang disembah. Formalitas ibadah keagamaan tidak akan menyentuh apa-apa jika dilakukan tanpa 'Roh.'13

Proskuneo adalah kata yang paling umum digunakan untuk penyembahan dalam Perjanjian Baru (lihat Yoh. 4:20-24; Why. 5:14), sama seperti hawah dalam Perjanjian Lama. Gagasan awal di balik kata tersebut adalah memberi penghormatan, menghormati dengan semangat penundukkan diri (dan mungkin juga sikap tubuh) kepada seseorang yang dianggap layak dan unggul. Seperti hawah, pada intinya ini adalah sikap hati yang dapat dicerminkan melalui sikap tubuh. Baik arti dan

\footnotetext{
${ }^{9}$ Matt Redman, Menyembah dalam Roh dan Kebenaran, cetakan keenam (Yogyakarta: Penerbit ANDI, 2010), 83.

${ }^{10}$ Redman, Menyembah dalam Roh dan Kebenaran, cetakan keenam, 81; H. Schonweiss dan C. Brown, New International Dictionary of New Testament Theology 2, 876. 2011), 26.

${ }^{11}$ John MacArthur, JR, Prioritas Utama dalam Penyembahan (Bandung: Kalam Hidup,

${ }^{12}$ Strong's Hebrew Greek Dictionaries, (e-Sword, 2010) s.v. proskuneô

13 Bagus Pramono," Yesus dan Perempuan Samaria," diakses 23 Februari 2015 , http://www.sarapanpagi.org/yesus-dan-perempuan-samaria-vt465.html.
} 
penggunaannya, kedua kata ini, hawah dan proskuneo, mempunyai kesejajaran yang sangat dekat. ${ }^{14}$

Dalam Perjanjian Baru, terdapat kata kerja Yunani yang bersama sejumlah kata yang lain yang berkaitan, mempunyai makna yang sesuai dengan abad. Kata-kata itu adalah latreuô dan leitourgeô. Kata latreuô ditemukan 21 kali dalam Perjanjian Baru dan berarti melayani/beribadah, menyembah. Semua kemunculan kata latreuô ada dalam konteks religius di mana pelayanan diberikan bukan bagi orang lain tetapi kepada Allah (Luk. 2:37; Kis.26:7; Flp. 3:3; Ibr. 12:28). ${ }^{15}$ Arti kata dalam ayat-ayat tersebut menunjukkan bagaimana seorang percaya melayani untuk Tuhan dengan pimpinan Roh Allah dengan cara yang berkenan kepadaNya dengan sikap hormat dan takut kepada-Nya.

Kata Yunani proskynêsis untuk "penyembahan" tidak muncul dalam Injil Yohanes, maupun di dalam seluruh Perjanjian Baru, tetapi 11 kali muncul kata proskynein dalam bentuk kata kerja di mana dalam Yohanes 4:20-24 muncul 9 kali saja, dan sekali muncul di dalam Yohanes 9:38 dan Yohanes 12:20. Kanagaraj menjelaskan bahwa arti penyembahan dalam Injil Yohanes bukanlah sebuah entitas (wujud) yang abstrak tetapi suatu tindakan yang sama seperti tindakan untuk percaya dan mengenal. Kata benda proskynêtês (penyembah) dinyatakan dalam bentuk jamak dalam 4:23. ${ }^{16}$ Hal itu berarti penyembahan adalah sesuatu yang berwujud yang dapat diekspresikan secara nyata yang ditujukan kepada Tuhan.

\section{Definisi Penyembahan}

Banyak pandangan tentang definisi penyembahan. Penyembahan adalah suatu respons manusia terhadap penerimaan kehadiran kudus, suatu kehadiran yang lebih penting dari aktivitas manusia normal dan kudus adanya. ${ }^{17}$ Marvin E. Tate mendefinisikan penyembahan dalam Alkitab bergerak terus di antara pengalaman pribadi dan bersama. Hal ini membawa manusia masuk ke dalam hubungan keintiman dengan Allah. Allah menciptakan manusia lebih utama untuk tujuan menyembah Dia. Panggilan ini untuk menyembah menunjukkan penyembahan sebagai prioritas universal dan satu-satunya tanggung jawab setiap orang percaya. Hal ini sangat jelas dinyatakan oleh A. W. Tozer, "we are here to be worshipers first and workers second." "Kami ada di sini

\footnotetext{
${ }^{14}$ Redman, Menyembah dalam Roh dan Kebenaran, 82.

${ }^{15}$ Ibid., 83.

${ }^{16}$ Jey J. Kanaragaraj, "Worship, Sacrifice and Mission: Themes Interlocked in John," Indian Journal of Theology 40.1\&2 (1998):17.

17 Marvin E. Tate, Holman Bible Dictionary for Window version l.og (Parsons Technology, 1994), s.v. "worship"
} 
pertama-tama menjadi penyembah-penyembah dan kedua sebagai pekerja-pekerja. ${ }^{18}$

Rob Harbison mendefinisikan penyembahan sebagai latihan spiritual kudus yang menghubungkan manusia dengan Allah melalui ekspresi hati yang mengasihi. Ia menambahkan bahwa ini sebagai proklamasi ketergantungan kepada Allah. ${ }^{19}$ Pandangan Kevin J. Conner, kata 'penyembahan' berarti bersujud, membungkuk lebih rendah atau merendahkan diri sendiri. ${ }^{20}$ Arti penyembahan dalam bahasa Ibrani adalah shachah. ${ }^{21}$ Menurut Ralph Mahoney, penyembahan adalah ekspresi kasih dan pujian kepada Allah. Penyembahan ini hanya dapat diekspresikan dengan memberi seluruh hati dan hidup kepada Dia. ${ }^{22}$ Berdasarkan Perjanjian Lama dalam Ulangan 6:5, "Kasihilah TUHAN, Allahmu, dengan segenap hatimu dan dengan segenap jiwamu dan dengan segenap kekuatanmu" (bdg. Mat 22:37).

Larmer Boscman mengatakan bahwa penyembahan bukanlah musik atau keterampilan musikal dan semuanya itu bukanlah keterampilan penyembahan. Instrumen musik di lain pihak tidak hanya untuk penyembahan tetapi dapat didedikasikan kepada Allah untuk digunakan sebagai bagian penyembahan. Kenyataan ini bahwa penyembahan bukanlah mekanik atau benda mati tetapi lebih daripada keadaan hati bukan suatu gaya musik. ${ }^{23}$ Andrew Brake mengatakan dalam bukunya Spiritual Formation: Menjadi Serupa dengan Kristus, bahwa apapun gaya kita dalam beribadah maka Allah akan menerima penyembahan itu asalkan memfokuskan penyembahan itu hanya kepada-Nya. ${ }^{24}$ Rick Warren yang menuliskan bahwa setiap bagian pelayanan gereja adalah tindakan penyembahan. Hal ini termasuk berdoa, pembacaan Alkitab, bernyanyi, pengakuan, mendengarkan khotbah, membuat catatan khotbah, memberi persembahan, baptisan, perjamuan kudus, usher (penerima

${ }^{18}$ A. W. Tozer, In Worship by the Book, Don Carson, (ed.) (Grand Rapids, Michigan: Zondervan, 2002), 151 .

${ }^{19}$ Rob Harbison, Worshiping God, Textbook - 525B3 (Lecture notes, Master of Divinity programme, Trinity Graduate School of Apologetics and Theology, India, 2008), 6- 7 .

${ }^{20}$ Kevin J. Conner, The Tabernacle of David (Poland:Oregon Bible Temple Conner Publications, 1992), 106.

${ }^{21}$ John R. Kohnberger III dan James A. Swanson, (eds.) The Strongest Strong's Exhaustive Concordance Of The Bible James Strong (Grand Rapids, Michigan: Zondervan, 2001), 1572, s.v. "shachah"

${ }^{22}$ Ralph Mahoney, Worship, Shepherd's Staff, New Believer's Training Manual, 7th Edition (India: World Map and Rekka Printers Pvt. Ltd, 2002), 33.

${ }^{23}$ Lamar Boschman, Praises and Worship: The Priority, Purpose and Portrayal of Worship (Lecture notes, International School of Ministry: The International Curriculum, Trimester 1. Good Shepherd Ministry International, USA, 2006), 87.

${ }^{24}$ Andrew Brake, Spiritual Formation: Menjadi Serupa dengan Kristus (Bandung: Kalam Hidup, 2014), 23. 
tamu) dan lain-lain. ${ }^{25}$ Pendapat di atas bahwa Allah menerima semua bentuk penyembahan yang didasarkan pada hati orang percaya yang terfokus kepada-Nya.

John MacArthur mendefinisikan penyembahan yang sejati adalah suatu respons kepada kebenaran kudus. Ini adalah gairah karena hal ini bangkit dari kasih kita untuk Allah. Tetapi untuk menjadi penyembah benar maka harus bangkit dari pemahaman yang benar tentang firmanNya, kebenaran-Nya, kemurahan-Nya, sifat-Nya. Penyembahan benar menyatakan Allah sebagaimana Dia telah menyatakan diri-Nya di dalam firman-Nya. Kita mengenal Dia dari Kitab Suci, misalnya bahwa hanya Dia kudus secara sempurna, Mahakuasa, Mahatahu, Mahahadir terpancar dari semua kebaikan, kemurahan, kebenaran, hikmat, kuasa, dan keselamatan. ${ }^{26}$

\section{Tinjauan Teologi Penyembahan Berdasarkan Yohanes 4:24}

Dave Hagelberg menyatakan bahwa "di antara segala perbedaan yang memisahkan bangsa Yahudi dan bangsa Samaria, tempat orang menyembah, merupakan salah satu yang paling pokok." ${ }^{27}$ Namun "di dalam tatanan baru yang dimulai dengan kedatangan Kristus, tempat penyembahan tidak sepenting tokoh yang disembah." ${ }^{28} \mathrm{~F}$. F. Bruce juga menekankan: "The important question is not where people worship God but how they worship him." "Tanggapan Tuhan Yesus terdiri dari tiga bagian. Pertama, (ayat 21), Dia memberitakan bahwa sebentar lagi kedua tempat ibadah menjadi usang; kedua (ayat 22), Dia menekankan bahwa keselamatan memang muncul dari umat Yahudi, bukan dari mereka (di luar Yahudi), dan ketiga (ayat 23-24), Dia menjelaskan mengenai sifat keselamatan itu." 30 Tuhan tidak disembah di tempat tertentu seperti di gunung atau di Yerusalem. Tuhan Mahahadir dan tidak dibatasi oleh tempat karena saat ini Tuhan ada dalam setiap hati orang percaya. Setiap orang percaya dapat menyembah setiap waktu dan di segala tempat dan dapat bersekutu dengan Dia, karena Dia ada di dalam setiap orang percaya.

\footnotetext{
${ }^{25}$ Rick Warren, Purpose Driven Life (Grand Rapid, Michigan: Zondervan, 2002), 65.

${ }^{26}$ John MacArthur, Worship The Ultimate Priority (Chicago: Moody Publisher, 2012), 37.

${ }^{27}$ Dave Hagelberg, Tafsiran Injil Yohanes Pasal 1-5 (Yogyakarta: Penerbit ANDI, 1999), 168.

${ }^{28}$ Everett F. Horrison, "Yohanes" dalam Tafsiran Alkitab Wycliffe Vol. 3 PB (Malang: Penerbit Gandum Mas, 2001), 316.

${ }^{29}$ F. F. Bruce, The Gospel Of John (Grand Rapid: William B.Eerdmans Publishing Company, 1983), 109.

${ }^{30}$ Hagelberg, Tafsiran Injil Yohanes Pasal 1-5, 169.
} 


\section{Allah itu Roh}

Allah adalah Pribadi pencipta layaknya penyembahan manusia. Allah adalah Roh, tidak terbatas, kekal dan tidak berubah dalam sifatNya. Allah adalah kudus, kebenaran, adil dan Allah yang penuh belas kasihan. Allah adalah pencipta dan pemberi kehidupan. Tidak ada pribadi, objek atau ide yang dapat dibandingkan dengan Allah. Allah adalah kudus di mana manusia berdosa tidak dapat datang ke dalam hadirat-Nya dan memiliki hubungan pribadi dengan-Nya sampai dosadosa mereka dihapuskan. ${ }^{31}$

Allah adalah Roh, Allah adalah Bapa. Dalam konteks yang sama di mana Yesus berkata, "Barangsiapa telah melihat Aku, ia telah melihat Bapa," (Yoh. 14:9). Sebelumnya Yesus berkata, "Tidak ada seorang pun yang datang kepada Bapa, kalau tidak melalui Aku" (Yoh. 14:6). Allah itu Roh, Bapa dan Yesus sendiri. Doktrin Tritunggal sangat penting bagi penyembahan yang benar. Yohanes 5:23 adalah kesimpulan logis dari pengajaran Yesus bahwa Allah secara unik adalah Bapa-Nya: "Supaya semua orang menghormati Anak sama seperti mereka menghormati Bapa. Barangsiapa tidak menghormati Anak, ia juga tidak menghormati Bapa, yang mengutus Dia." "Menghormati" adalah sebuah kata yang menyiratkan penyembahan. Kita tidak hanya harus menyembah Bapa; kita harus menyembah Anak juga. ${ }^{32} \mathrm{Hal}$ itu memberikan implikasi bahwa satu-satunya cara menyembah Bapa adalah menyembah Anak. Perspektif benar tentang penyembahan adalah Allah dapat disembah hanya bila Bapa disadari menjadi satu dengan Anak-Nya, yang harus menerima penghormatan seperti Bapa. Untuk menyembah Allah yang adalah pribadi sekaligus Roh maka kita harus menyembahnya dalam roh kita. Tetapi sebelumnya roh kita harus diperbarui oleh Roh Kudus yaitu Roh Allah sendiri. Roh Kudus membawa kerinduan kepada Yesus yang menghantarkan kita kepada Allah.

Horrison mengatakan,

"Hal yang penting ialah bahwa orang menyembah Bapa, yang sudah diberitakan melalui kedatangan Sang Anak. Keselamatan datang dari bangsa Yahudi di dalam arti bahwa penyataan khusustentang cara mendekati Allah dengan benar disampaikan kepada mereka: dan Yesus sendiri, Sang Juruselamat, berasal dari bangsa ini (Rom. 9:5). Bahkan sebelum sistem keagamaan yang baru diresmikan dengan sifatnya yang universal, para penyembah sejati memperoleh kehormatan untuk menyembah Allah sebagai Bapa di dalam roh dan kebenaran. Sedangkan

\footnotetext{
${ }^{31}$ Peter White, Developing A Theology Of Worship For Today: A Case Study Of Leviticus 17: 11 (India: Trinity Graduate School of Apologetics and Theology, 2011), 5.

${ }^{32}$ John MacArthur, Jr, Prioritas Utama dalam Penyembahan (Bandung: Kalam Hidup, 2011), 145 .
} 
kebenaran bertentangan dengan penyembahan orang Samaria yang tidak memadai dan palsu. Cara menyembah yang baru ini merupakan keharusan, sebab Allah itu Roh adanya." 33

\section{Manusia Menyembah Allah}

Manusia adalah serupa dan gambar-Nya, manusia diciptakan untuk memiliki kedekatan dengan Allah; dan ketika hubungan itu terputus maka manusia menjadi tidak lengkap dan membutuhkan pemulihan. Komuni dengan Allah yang hidup adalah inti sari penyembahan. Manusia diciptakan berbeda dengan binatang dalam hal hati nurani moralnya, pengenalan diri sendiri dan kapasitas untuk perjumpaan spiritual dengan penciptanya. Semua manusia dalam pandangan ini memiliki dua aspek yaitu tubuh dan rohani (tubuh dan jiwa, atau tubuh dan pikiran, atau tubuh dan roh) dan kapasitasnya berhubungan erat keduanya antara ciptaan dan Pencipta mereka. Kapasitas ini juga telah dirusak, dan disalahgunakan karena dosa. ${ }^{34}$ Tuhan mengembalikan hubungan yang rusak melalui Yesus Kristus sehingga orang yang percaya dapat datang menyembah Tuhan secara pribadi.

Manusia menyembah Allah yang benar adalah Bapa yaitu sebutan kesukaan Yesus untuk Allah. Tiga kali dalam Yohanes 4, Yesus berbicara tentang menyembah "Bapa" $(4: 21,23)$. Yesus sendiri menegaskan kepada iblis dengan perkataan ini, "Sebab ada tertulis: Engkau harus menyembah Tuhan, Allahmu, dan hanya kepada Dia sajalah engkau berbakti!" (Matius 4:10b).

\section{Menyembah dalam Roh}

Injil Yohanes 4:23-24, "Tetapi saatnya akan datang dan sudah tiba sekarang, bahwa penyembah-penyembah benar akan menyembah Bapa dalam roh dan kebenaran... Allah itu Roh dan barangsiapa menyembah Dia, harus menyembah-Nya dalam roh dan kebenaran." Apa yang dimaksudkan dengan menyembah dalam roh? Kata "roh" dalam ayat 24 mengacu kepada roh manusia, pribadi yang lebih dalam. Penyembahan haruslah mengalir dari dalam ke luar. ${ }^{35}$

Bob Sorge mengemukakan: "Yesus sedang menunjukkan bahwa penyembahan tidak lagi diikat pada waktu atau tempat tertentu (bukan di Yerusalem, di mana orang-orang Yahudi menyembah; bukan juga di gunung Gerizim, di mana orang-orang Samaria menyembah); melainkan

${ }^{33}$ Everett F. Horrison, "Yohanes" dalam Tafsiran Alkitab Wycliffe Vol. 3 PB (Malang: Penerbit Gandum Mas, 2001), 315-317.

${ }^{34}$ J. D. Douglass dan Merrill C. Tenney, eds., The New International Dictionary of the Bible, Pictorial Edition (Grand Rapids, Michigan: Zondervan Publishing House, 1987), 617-618.

${ }^{35}$ MacArthur, Prioritas Utama dalam Penyembahan, 151. 
akan menjadi suatu pekerjaan roh manusia menggapai Roh Tuhan. Yesus tahu saatnya segera datang yang mana korban-korban hukum Musa di Yerusalem tidak lagi diperlukan, dan penyembahan akan terjadi di dalam rumah Perjanjian Baru - manusia sendiri (lihat 1 Kor. 3:16). Penyembahan sekarang dapat terjadi setiap saat, di mana saja orang yang penuh Roh berada." William Barclay juga menyatakan: "Membatasi ibadah kepada Allah hanya di Yerusalem atau tempat-tempat lain yang tertentu saja adalah sama dengan memberi batas kepada Dia yang menurut hakikatNya sendiri tidak terbatas." ${ }^{37}$

\section{Menyembah dalam Kebenaran}

Menyembah Allah bukan hanya dalam roh tetapi juga dalam kebenaran. "Penekanan "roh" ( "kebenaran" ( $\alpha \lambda \eta \theta \varepsilon ı \alpha$-alêtheia) ini harus dilakukan oleh penyembahpenyembah yang "sejati" ( $\alpha \lambda \eta \theta$ vvos-alethinos). ${ }^{38}$ James Montgomery Boice mengungkapkan,

"For Jesus said that those who acknowledge God's true worth must do so "in spirit and in truth." In other words, they must do so "in truth" because truth has to do with what His nature is, and they must do so "in spirit" because they can only apprehend it spirituality." 39

Selanjutnya, menurut James Montgomery Boice menyembah dalam kebenaran memiliki tiga arti:

"First, it means that we must approach God truthfully, that is, honestly or wholeheartedly; Second we must worship on the basis of the biblical revelation; Finally, to God "in truth" also means that we must approach God Christocentrically. This is means "in Christ," for this is God's way of approach to Him. ${ }^{40}$

Pernyataan Boice di atas, orang percaya menyembah dalam kebenaran karena itu adalah sifat-Nya. Menyembah dalam roh karena Dia hanya dapat dialami secara rohani. Melalui penjelasan di atas menyembah dalam kebenaran adalah penyembah yang menyembah Allah

${ }^{36}$ Bob Sorge, Mengungkap Segi-Segi Pujian dan Penyembahan (Yogyakarta: Penerbit ANDI, 1991), 63.

37 William Barclay, Pemahaman Alkitab Setiap Hari (Jakarta: BPK Gunung Mulia, 1983), 273.

38 Bagus Pramono,"Yesus dan Perempuan Samaria," diakses 23 Februari 2015, http:// www.sarapanpagi.org/yesus-dan-perempuan-samaria-vt465.html

39 James Montgomery Boice, The Gospel of John V 1 (Grand Rapids: Zondervan Publishing House, 1981), 365.

${ }^{40}$ Boice, The Gospel of John V 1, 368. 
dengan keterbukaan dan segenap hati, berfokus kepada kebenaran Allah dan berfokus kepada Kristus.

Menyembah dalam kebenaran berarti "tidak menyembunyikan rahasia." Kita berdiri secara nyata, terbuka di hadapan-Nya, dengan tidak menyembunyikan sesuatu. Seperti Imam Mahatinggi, kita harus menyiapkan diri kita untuk masuk kedalam hadirat-Nya. Seluruh dosa harus di ampuni dan ditahirkan oleh darah Yesus. "Jika kita mengaku dosa kita, maka Ia adalah setia dan adil, sehingga Ia akan mengampuni segala dosa kita dan menyucikan kita dari segala kejahatan" (1 Yoh. 1:9). ${ }^{41}$

Yesus menghubungkan penyembahan dengan kebenaran tanpa dapat dipisahkan. Penyembahan bukanlah suatu pengalaman emosi dengan firman Allah yang menimbulkan perasaan-perasaan tertentu. Penyembahan adalah tanggapan yang dibangun atas kebenaran. Mazmur 145:18 mengatakan, "TUHAN dekat pada setiap orang yang berseru kepada-Nya, pada setiap orang yang berseru kepada-Nya dalam kesetiaan.."

\section{Menyembah dalam Roh dan Kebenaran}

Secara utuh pembicaraan Tuhan Yesus dengan perempuan Samaria adalah tentang ibadah yang benar kepada Allah. Ibadah itu berasal dari kata "menyembah." Dan konsep teologis penyembahan dalam arti yang luas sebenarnya berkaitan dengan keberadaan orang percaya di hadapan Allah.

Untuk memahami secara utuh tentang konsep teologis menyembah dalam roh dan kebenaran, maka kita harus kembali kepada esensi utamanya dan tidak terjebak kepada hal-hal praktis yang sebenarnya lebih kepada ekspresi.

\section{Menyembah: Relasi dengan Allah sesuai Firman-Nya}

Hal yang prinsip dalam menerjemahkan menyembah Allah dengan roh dan kebenaran adalah bagaimana kita berelasi dengan Tuhan sesuai dengan firman-Nya. Mengenal pribadi Allah dengan benar, sesuai dengan apa yang Dia ajarkan.

Bait Allah adalah tempat di mana Allah bersekutu dengan umatNya. Konsep bait Allah di dalam Alkitab mengalami perubahan yang revolusioner. Di dalam Perjanjian Lama bait Allah adalah bangunan secara fisik, namun di dalam Perjanjian Baru bait Allah adalah tubuh dan pribadi orang percaya. Dalam 1 Korintus 6:19, "Atau tidak tahukah

${ }^{41}$ A. L. Gill dan Joyce Gill, "Pujian dan Penyembahan Menjadi PenyembahPenyembah Tuhan," diakses 20 Februari 2015, http://www.gillministries.com/PDF\%20 files/Indonesian\%20P\&W.pdf

${ }^{42}$ John MacArthur, Jr, Prioritas Utama dalam Penyembahan, 157. 
kamu, bahwa tubuhmu adalah bait Roh Kudus yang diam di dalam kamu, Roh Kudus yang kamu peroleh dari Allah, dan bahwa kamu bukan milik kamu sendiri?"

Secara teologis meskipun mengalami perubahan secara revolusioner namun esensi bait Allah tetap merupakan tempat persekutuan antara Allah dengan umat-Nya. Kemah Suci zaman Musa dibangun sebagai kehendak Allah untuk bersekutu dengan umat-Nya. Keluaran 29:45, "Aku akan diam di tengah-tengah orang Israel dan Aku akan menjadi Allah mereka." Di dalam persekutuan dengan Allah, umat-Nya harus mempersembahkan tubuhnya sebagai persembahan yang hidup. Roma 12:1, "Karena itu, saudara-saudara, demi kemurahan Allah aku menasihatkan kamu, supaya kamu mempersembahkan tubuhmu sebagai persembahan yang hidup, yang kudus dan yang berkenan kepada Allah: itu adalah ibadahmu yang sejati."

Di dalam konteks hidup sebagai persembahan inilah kehadiran Allah nyata pada diri umat-Nya dan penyembahan mengalir dari kehidupan umat-Nya. Di dalam makna ini juga penyembahan melibatkan seluruh aspek kehidupan. William Barclay menyatakan,

Kalau Allah itu roh, maka persembahan manusia kepada Allah haruslah juga persembahan roh. Persembahan korban binatang dan barang-barang lain buatan manusia tidaklah cukup. Persembahan yang berkenan kepada hakikat Allah hanya persembahan roh, yaitu kasih, kesetiaan, ketaatan dan penyerahan diri. ${ }^{43}$

Selanjutnya sebagai bait Allah, Roma 12:1-2, "Janganlah kamu menjadi serupa dengan dunia ini, tetapi berubahlah oleh pembaharuan budimu, sehingga kamu dapat membedakan manakah kehendak Allah: apa yang baik, yang berkenan kepada Allah dan yang sempurna." Sebagai bait Allah orang percaya harus hidup sesuai kehendak Allah. Kebenaran yang Allah berikan melalui fiman-Nya.

\section{Menyembah: Ekspresi Pengagungan Tuhan}

Relasi dengan Allah secara umum adalah di dalam seluruh aspek kehidupan dan secara khusus merupakan persekutuan pribadi dan ibadah di gereja. Ibadah gereja merupakan persekutuan umat dengan Allah. Di dalam ibadahlah umat memuji dan mendengarkan firman Allah. R. C. Sproul seorang teolog Injili menjelaskan:

"Ketika kita beribadah, kita membawa seluruh diri kita ke dalam tindakan berbakti kepada Allah dan berkomunikasi dengan Allah. Ada banyak cara untuk melakukan hal ini. Manusia bukan makhluk yang sederhana,

\footnotetext{
${ }^{43}$ Barclay, Pemahaman Alkitab Setiap Hari, 273.
} 
melainkan bersifat kompleks. Jika kita dengan teliti menyelidiki apa yang tertulis di dalam Kitab Suci bahwa kita harus menyembah Allah dengan seluruh jiwa, dengan seluruh tubuh dan dengan seluruh panca indra kita, maka kita akan mempunyai suatu pandangan baru tentang beribadah." ${ }^{44}$

Selanjutnya Sproul mengatakan pula:

"Penglihatan, pendengaran, perasaan, sentuhan, penciuman; semuanya tercakup dalam pengalaman manusia. Kita dipengaruhi oleh panca indra dan juga dipengaruhi oleh pikiran. Pikiran kita, tubuh kita, jiwa kita, hati kita, seluruh diri kita harus terlibat di dalam ibadah. Saya yakin bahwa jika kita membuang salah satu segi kemanusiaan kita, berarti kita membuat ibadah kita menjadi miskin.. ${ }^{45}$

Ron Jenson dan Jim Stevens berpendapat, "Menyembah adalah mengadakan kontak dengan Allah, berdoa kepada Allah, memuji, menyanyi kepada Allah, mengaku di hadapan Allah dan memberi tanggapan kepada Allah sebagaimana Ia telah ditinggikan dan dinyatakan dalam firman-Nya. Tujuannya adalah untuk memberi sesuatu, bukan untuk menerima sesuatu. Berkat pasti akan datang, karena menerima adalah hasil dari memberi." ${ }^{46}$

Bagi kalangan pietis apostolik baru, penyembahan merupakan realitas dari pengagungan Tuhan dengan melibatkan seluruh panca indra dan emosi. Bahkan ada yang mengharuskan penyembahan dengan berbahasa roh. Salah satu penghormatan kita kepada Allah melalui sikap ekspresi kita kepada-Nya dalam ibadah.

Meskipun tidak memberikan penyelesaian akhir, namun persoalan pokok tentang penyembahan sebenarnya bermuara pada dua kubu "intelektual dan ekspresi." "Suatu kubu menyatakan bahwa perasaan religius adalah esensi kerohanian sejati. Apa yang Anda percayai atau lakukan tidaklah begitu penting, asalkan kasih Tuhan kepada jiwa Anda bisa Anda rasakan." 47 Sementara yang lain berpendapat "inti dari kerohanian yang sejati adalah berpikir benar. Para pendukung pandangan ini berpendapat bahwa perasaan tidaklah terlalu penting dibandingkan doktrin dan sikap mental. Menurut mereka, keyakinan yang benar membuat jiwa tetap terikat pada fondasi kebenaran,

${ }^{44}$ R. C. Sproul, Menanggapi Allah dalam Ibadah (Malang: Penerbit Gandum Mas, 2002), 550 .

${ }^{45}$ Sproul, Menanggapi Allah dalam Ibadah, 551.

${ }^{46}$ Ron Jenson dan Jim Stevens, Dinamika Pertumbuhan Gereja (Malang: Penerbit Gandum Mas,1996), 41.

${ }^{47}$ Gerald R. McDermott, Mengenali 12 Tanda Kerohanian Sejati (Yogyakarta: Penerbit ANDI, 1995), 31. 
sementara perasaan sifatnya berubah-ubah dan sering menyeret orang yang tidak tahu kepada kesia-siaan., ${ }^{48}$

John MacArthur memberikan kesimpulan yang baik: "Ketulusan, kegairahan, dan sikap agresif penting, tetapi semua itu harus didasarkan kepada kebenaran. Dan kebenaran adalah dasar, tetapi bila tidak menghasilkan hati yang berhasrat, gembira dan bergairah, penyembahan tersebut tidak lengkap." Bob Sorge mengatakan bahwa "Tidak ada satu definisi pun yang tampaknya dapat mengekpresikan secara tepat tentang penyembahan secara lengkap mungkin karena penyembahan adalah pertemuan ilahi sehingga kedalamannya tidak sebatas sebagaimana Allah sendiri." ${ }^{49}$

Tuhan Yesus menghendaki kita sadar bahwa penyembahan merupakan proses respons atau tanggapan roh kita. Penyembahan tidak hanya melibatkan gerakan tubuh yang dapat dilihat. Penyembahan harus keluar dari roh kita-bagian terdalam manusia. Penyembahan tidak bergantung pada hal-hal luar, seperti tempat tertentu, keadaan sekeliling yang indah, tata cara yang sudah lazim, musik khusus, atau gerakan tubuh. ${ }^{50}$ Dengan atau tanpa hal-hal luar itu, kita dapat menyembah Allah Bapa "dalam roh." Yesus sendiri menegaskan kepada perempuan Samaria katanya: "Percayalah kepada-Ku, hai perempuan, saatnya akan tiba, bahwa kamu akan menyembah Bapa bukan di gunung ini dan bukan juga di Yerusalem.." ${ }^{51}$ Hal ini berarti bahwa penyembahan itu bersumber dari dalam hati yang mengalir keluar dan berdampak pada tubuh kita. Penyembahan itu tidak merujuk kepada tempat menyembah, tetapi dengan hati yang menyembah.

Dalam Yohanes 4:7-15, memberi sekilas pandangan tentang apa artinya menyembah dalam roh. Kalau roh kita mati, jauh dari Allah, maka kita tidak dapat menyembah Dia. Tetapi kalau Roh Allah bersatu dengan roh kita, maka roh kita akan bergerak untuk bersekutu dengan Allah yang hidup. Hal itu terjadi pada saat kita dengan iman menerima Yesus Kristus sebagai Juruselamat dan Tuhan kita. Pada saat itulah kita pertama kali minum air kehidupan yang ditawarkan-Nya secara cumacuma. Air kehidupan dari Roh Allah itu kemudian menjadi mata air di dalam diri kita, memungkinkan kita mengalami kehidupan yang kekal dan yang berkelimpahan. ${ }^{52}$ Dia seperti aliran-aliran air hidup yang keluar

\footnotetext{
${ }^{48}$ McDermott, Mengenali 12 Tanda Kerohanian Sejati, 31.

${ }^{49}$ Bob Sorge, Mengungkap Segi-Segi Pujian dan Penyembahan (Yogyakarta: Penerbit ANDI, 1991), 51.

${ }^{50}$ Warren dan Ruth Myers, Praise: A Door to God's Presence (Jakarta: Lembaga Literatur Baptist, 2004), 40.

${ }^{51}$ Injil Yohanes 4:21.

${ }^{52}$ Warren dan Ruth Myers, Praise: A Door to God's Presence (Jakarta: Lembaga Literatur Baptist, 2004), 41.
} 
dari hati orang percaya dan orang percaya yang haus akan Dia dipuaskan dan tidak akan pernah lagi haus karena rasa dahaga itu telah dipuaskan ketika menyembah Dia dalam roh.

\section{Menyembah: Relasi dengan Allah Trinitas}

Menyembah dalam Roh adalah kegiatan rohani yang dipimpin Roh Allah. Roh Kudus membantu Anda menyembah. Anda tidak bisa melakukan itu tanpa Dia. Dia harus tinggal di dalam Anda. Roh Kudus menjadi satu dengan roh Anda. Dia mengajarkan Anda semua yang perlu Anda ketahui. Dia mengantar roh Anda kepada Allah. Dia memberi Anda nada dan irama untuk dinyanyikan. ${ }^{53}$

Kita dapat mempunyai hati yang melimpah, yang menyembah dalam roh. Pertama, diri kita harus diserahkan kepada Roh Kudus. Sebelum kita dapat menyembah Allah dalam roh, Roh Kudus harus ada untuk menghasilkan penyembahan yang benar. Dalam 1 Korintus 2:1l mengatakan, "Demikian pulalah tidak ada orang yang mengetahui, apa yang terdapat di dalam diri Allah selain Roh Allah." Bila Anda tidak membiarkan Roh Allah mendorong hati Anda, memotivasi hati Anda, menyucikan hati Anda, Anda tidak dapat menyembah Allah karena Anda bahkan tidak dapat mengenal Dia. ${ }^{54}$ Kedua, bila kita ingin menyembah dalam roh, pikiran kita harus dipusatkan kepada Allah. Penyembahan adalah luapan dari pikiran yang diperbarui oleh kebenaran Allah. Kita menyebut proses tersebut perenungan. Inti dari renungan adalah penemuan, suatu pengertian akan kebenaran Allah. Dan penemuan dialami pada waktu kita bersekutu dengan Allah dalam doa dan firmanNya. Roh-Nya mengajarkan kepada kita kebenaran dari firman tersebut ketika kita belajar dan mengadakan renungan sambil berdoa dengan sepenuh hati. ${ }^{55}$

\section{Menyembah: Sikap Hati dan Respons dalam Penyembahan}

Pemaparan John MacArthur lebih mewakili gereja diluar aliran pietis. Ia memberikan pengertian penyembahan sebagai keseluruhan hidup orang percaya: "Pengertian kita tentang penyembahan diperkaya ketika kita memahami bahwa penyembahan sejati menyentuh setiap bidang kehidupan. Kita harus menghargai dan memuja Allah dalam segala hal. ${ }^{.56}$

\footnotetext{
${ }^{53}$ Ted C. Stewart, Higher Level Worship (Yogyakarta: Penerbit ANDI, 2007), 240.

${ }^{54}$ John MacArthur, Prioritas Utama dalam Penyembahan (Bandung: Kalam Hidup, 2001), 153

${ }_{55}^{55}$ MacArthur, Prioritas Utama dalam Penyembahan, 153.

${ }^{56}$ Ibid., 29.
} 
"Memuji Allah, berbuat baik, dan memberi bantuan kepada orang lain, semua adalah tindakan penyembahan yang benar dan alkitabiah." Rick Warren menegaskan: "mempersembahkan diri kita kepada Allah itulah yang dimaksud dengan penyembahan.. ${ }^{58} \mathrm{Hal}$ ini berarti penyerahan diri dengan segenap hati adalah penyembahan yang sejati yang dapat dilakukan oleh orang percaya yang telah dipenuhi hatinya dengan Roh Kudus-Nya.

John MacArthur membagi penyembahan dalam tiga dimensi yaitu: "Pertama, dapat tercermin dalam bagaimana kita bersikap terhadap orang lain (Rom. 14:18). Penyembahan dapat dinyatakan dengan membagi kasih dengan sesama orang percaya, mengabarkan Injil kepada orangorang yang tidak percaya, dan memenuhi kebutuhan umat pada tingkat yang sangat jasmani. Penyembahan yang berkenan kepada Allah adalah memberi, yaitu kasih yang membagi; Kedua, melibatkan tingkah laku pribadi (Ef. 5:8-10). Kata berkenan dalam kalimat ujilah apa yang berkenan kepada Tuhan adalah dari bahasa Yunani yang berarti "dapat diterima." Dalam konteks ini, ia mengacu kepada kebaikan, keadilan dan kebenaran, yang jelas berarti bahwa berbuat baik adalah tindakan yang dapat diterima sebagai penyembahan kepada Allah; Ketiga, dimensi ke atas (Ibr. 13:15-16), penyembahan itu adalah ucapan syukur dan pujipujian. ${ }^{59}$

Sikap-sikap dalam menyembah pada dasarnya dimulai dari sikap hati. Pertama, untuk menyembah dalam roh, kita harus mempunyai hati yang tidak bercabang. Seseorang dengan hati yang bercabang mungkin memiliki maksud yang baik, tetapi ia menemukan ketika ia duduk untuk berdoa dan bersekutu dengan Tuhan, sejuta hal lain membanjiri pikirannya. ${ }^{60}$ Kedua, hati yang hancur merupakan sikap mula-mula yang baik untuk menyembah, karena air mata bisa membersihkan jiwa. Ketika kita dengan segala ketidaksempurnaan kita berdiri di hadirat Kristus yang betul-betul sempurna, maka perbedaan yang menonjol sudah cukup untuk menghancurkan hati kita. ${ }^{61}$ Hati yang remuk adalah korban yang menyenangkan Tuhan (Mzm. 5l:9). Hati yang remuk adalah hati yang bertobat. ${ }^{2}$ Hati yang remuk berarti hati yang penuh penyesalan atas segala dosa dan kejahatan. Relakan hati kita untuk diselidiki oleh Allah dan melalui pengakuan kita yang jujur di hadapan Tuhan maka

${ }^{57}$ MacArthur, Prioritas Utama dalam Penyembahan, 29.

${ }^{58}$ Rick Warren, Kehidupan Yang Digerakkan Oleh Tuhan (Malang: Penerbit Gandum Mas, 2005), 86.

${ }^{59}$ MacArthur, 28-29.

${ }^{60}$ MacArthur, 54.

${ }^{61}$ Judson Cornwall, Let Us Worship (Yogyakarta: Penerbit ANDI, 2006), 80.

${ }^{62}$ Abraham Soei Ndoen, Revolusi Penyembahan Profetik (Yogyakarta: Penerbit ANDI, 2007), 38 . 
kita memperoleh pengampunan dan pemulihan dari-Nya (Mzm. 139:2324). Ketiga, kerendahan hati. Lukas mencatat bahwa seorang perempuan berdosa "membasahi kaki-Nya itu dengan air matanya dan menyekanya dengan rambutnya..." (Luk. 7:38). Tindakan menyeka kaki Kristus dengan rambut memperlihatkan sikap rendah hati. ${ }^{63}$ Keempat, penyembahan yang didasari oleh kasih dan bukan dimulai oleh motivasi yang keliru. Kita datang menyembah di hadapan-Nya karena Dia telah terlebih dahulu mengasihi kita dan kasih harus menjadi inti dari segala bentuk penyembahan. Kelima, tindakan penyembahan adalah sikap memberi, karena perempuan berdosa mencurahkan isi buli-buli pualam itu kepada Yesus. Keenam, Tuhan Yesus menghendaki kita sadar bahwa penyembahan merupakan respons atau tanggapan roh kita. Warren dan Ruth Myers menjelaskan, "Penyembahan tidak hanya melibatkan gerakan tubuh yang dapat dilihat. Penyembahan harus keluar dari roh kita, bagian terdalam dari manusia. Penyembahan tidak bergantung pada hal-hal luar, seperti tempat tertentu, keadaan sekeliling yang indah, tata cara yang sudah lazim, atau gerakan tubuh..64 Ketujuh, Melalui pertobatan perempuan Samaria membawanya kepada hidup yang menyembah. Penyembahan menghasilkan motivasi untuk menginjil. Penyembahan menghasilkan suatu kerinduan untuk menceritakan kepada orang lain tentang Yesus Kristus. ${ }^{65}$

Injil Yohanes dengan jelas telah menggeser pemahaman tradisional dari tempat penyembahan menuju objek dan cara penyembahan. Objek penyembahan adalah Allah dan siap yang menyembah Dia seharusnya mengakui dan mengalami Dia sebagai Bapa. Dia adalah Allah yang membawa keselamatan ke dunia melalui pengorbanan-Nya dan sejarah Yahudi dan terutama di dalam Yesus Kristus. ${ }^{66}$

\section{Kesimpulan}

Penyembahan hanya ditujukan kepada Allah. Penyembahan kepada Allah adalah sikap hati yang benar dan respons terhadap Allah dan mengalaminya secara pribadi di hadapan-Nya. John MacArthur mendefinisikan penyembahan yang sejati adalah suatu respons kepada kebenaran kudus. Ini adalah gairah karena hal ini bangkit dari kasih kita

${ }^{63}$ Cornwall, 82.

${ }^{64}$ Warren dan Ruth Myers, Pujian dan Penyembahan (Bandung: Lembaga Literatur Baptis, 2004), 40.

65 Stefany John Risna Abrahamsz dan Petronella Nelly Tuhumury, "Model

Penginjilan dalam Yohanes 4:4-42 dan Implementasinya pada Masa Kini," Jurnal Jaffray 10, no. 2 (Oktober 2012): 135.

${ }^{66}$ Jay J. Kanagaraj, "Worship, Sacrifice and Mission: Themes Interlocked in John," Indian Journal of Theology 40.1\&2 (1998):35. 
untuk Allah. Tetapi untuk menjadi penyembah benar maka harus bangkit dari pemahaman yang benar tentang firman-Nya, kebenaranNya, kemurahan-Nya, sifat-Nya. Penyembahan benar menyatakan Allah sebagaimana Dia telah menyatakan diri-Nya di dalam firman-Nya. Penyembahan yang sejati menurut Alkitab adalah menyembah Allah yang benar di dalam roh yang diperbarui oleh Roh Kudus dan hidup sesuai dengan kebenaran Allah yaitu mengenal pribadi Yesus sebagai air hidup. Penyembahan kepada Allah Tritunggal secara menyeluruh menghadirkan tiga pribadi yang satu.

Implikasi teologis biblika adalah: Allah adalah Roh maka Allah harus disembah di dalam roh (batiniah yang diperbarui oleh Roh Kudus) dan tidak disembah secara lahiriah saja atau yang tampak secara jasmani. Allah saja yang harus disembah oleh manusia, tidak ada yang lain. Secara praktis orang percaya harus menyembah Allah dengan sikap yang benar yang dibarui oleh Roh Kudus dan hidup sesuai dengan kebenaran-Nya.

\section{Kepustakaan}

Abrahamsz, Stefany John Risna dan Petronella Nelly Tuhumury. "Model Penginjilan dalam Yohanes 4:4-42 dan Implementasinya pada Masa

Kini," Jurnal Jaffray 10, no. 2 (Oktober 2012): 104-139.

Barclay, William. Pemahaman Alkitab Setiap Hari. Jakarta: BPK Gunung Mulia, 1983.

Boice, James Montgomery. The Gospel of John V 1. Grand Rapids, Zondervan Publishing House, 1981.

Boschman, Lamar. Praises and Worship: The Priority, Purpose and Portrayal of Worship. Lecture notes, International School of Ministry: The International Curriculum, Trimester 1. Good Shepherd Ministry International, USA, 2006.

Bruce, F. F. The Gospel of John. Grand Rapids: William B. Eerdmans Publishing Company, 1983.

Conner, Kevin J. The Tabernacle of David. Poland: Oregon Bible Temple Conner Publications, 1992.

Cornwall, Judson. Let Us Worship. Jakarta: Penerbit ANDI, 2009.

Feiffer, Charles F. P. dan Everett F.Horrison. Tafsiran Alkitab Wycliffe Vol. 3 PB. Malang: Penerbit Gandum Mas, 2001.

Gill, A. L. dan Joyce Gill, "Pujian dan Penyembahan Menjadi PenyembahPenyembah Tuhan." Diakses 23 Februari 2015. http://www.gillministries.com/PDF\%20files/Indonesian\%20P\&W. pdf

Handoyo, Djohan E. Praise and Worship. Yogyakarta: Penerbit ANDI, 2007. 
Harbison, Rob. Worshiping God, Textbook - 525B3. Lecture Notes, Master of Divinity programme, Trinity Graduate School of Apologetics and Theology, India, 2008.

Hagelberg, Dave. Tafsiran Injil Yohanes Pasal 1-5. Yogyakarta: Penerbit ANDI, 1999.

Jenson, Ron dan Jim Stevens. Dinamika Pertumbuhan Gereja. Malang: Penerbit Gandum Mas, 1996.

Kanagaraj, Jay J. "Worship, Sacrifice and Mission: Themes Interlocked in John.” Indian Journal of Theology 40.1\&2 (1998):16-39.

Kohnberger III, John R. dan James A. Swanson. The Strongest Strong's Exhaustive Concordance of The Bible James Strong. Grand Rapids, Michigan: Zondervan, 2001.

MacArthur Jr, John. Prioritas Utama dalam Penyembahan. Bandung: Kalam Hidup, 2001.

McDermott, Gerald R. Mengenali 12 Tanda Kerohanian Sejati. Yogyakarta: Penerbit ANDI, 1995.

Mahoney, Ralph. Worship, Shepherd's Staff, New Believer's Training Manual, 7th Edition. India: World Map and Rekka Printers Pvt. Ltd, 2002.

Pramono, Bagus. "Yesus dan Perempuan Samaria." Diakses 23 Februari 2015. http://www.sarapanpagi.org/yesus-dan-perempuan-samariavt465.html

Redman, Matt. Menyembah dalam Roh dan Kebenaran Cetakan Keenam. Yogyakarta: Penerbit ANDI, 2010.

Sarapan Pagi," Penyembah Sejati." Diakses tanggal 23 Februari 2015. http:// www.sarapanpagi.org/penyembahsejati-vt283.html

Sorge, Bob. Mengungkap Segi-Segi Pujian dan Penyembahan. Yogyakarta: Penerbit ANDI,1991.

Sproul, R.C. Menanggapi Allah dalam Ibadah. Malang: Penerbit Gandum Mas, 2002.

Stewart, Ted C. Higher Level Worship. Yogyakarta: Penerbit ANDI, 2007,

Tozer, A. W. In Worship by the Book, Don Carson, (ed.). Grand Rapids, Michigan: Zondervan, 2002.

Warren, Rick. Purpose Driven Life. Grand Rapids, Michigan: Zondervan, 2002.

Warren dan Ruth Myers. Pujian dan Penyembahan. Bandung: Lembaga Literatur Baptis, 2004.

White, Peter. Developing A Theology Of Worship For Today: A Case Study Of Leviticus 17: 11. India: Trinity Graduate School of Apologetics and Theology, 2011. 